\title{
Status of the undisturbed mangroves at Brunei Bay, East Malaysia: a preliminary assessment based on remote sensing and ground-truth observations
}

\author{
Behara Satyanarayana ${ }^{\text {Corresp., }}{ }_{1,2}$ ， Aidy M. Muslim ${ }^{\text {Corresp., }}{ }^{1}$ ， Nurul Amira Izzaty Horsali ${ }^{1}$, Nurul Ashikin Mat Zauki \\ , Viviana Otero ${ }^{2}$, Muhammad Izuan Nadzri ${ }^{1}$, Sulong Ibrahim ${ }^{1}$, Mohd-Lokman Husain ${ }^{1}$, Farid Dahdouh- \\ Guebas ${ }^{2,3}$ \\ 1 Universiti Malaysia Terengganu - UMT, Mangrove Research Unit (MARU), Institute of Oceanography and Environment (INOS), Kuala Terengganu, Malaysia \\ 2 Université Libre de Bruxelles - ULB, Laboratory of Systems Ecology and Resource Management, Brussels, Belgium \\ 3 Laboratory of Plant Biology and Nature Management, Vrije Universiteit Brussel, Brussels, Belgium \\ Corresponding Authors: Behara Satyanarayana, Aidy M. Muslim \\ Email address: satyam@umt.edu.my, aidy@umt.edu.my
}

Brunei Bay - receiving freshwater discharge from the four major rivers namely, Limbang, Sundar, Weston and Menumbok, hosts a luxuriant mangrove cover in East Malaysia. However, this relatively undisturbed mangrove forest has been less scientifically explored especially in terms of vegetation structure, ecosystem services and functioning, and landuse/cover changes. In the present study, mangrove areal extent together with species composition and distribution at the four notified estuaries was evaluated through remote sensing (Advanced Land Observation Satellite - ALOS) and ground-truth (Point-Centred Quarter Method - PCQM) observations. As of 2010, the total mangrove cover was found to be ca. 35,183.74 ha, of which Weston and Menumbok occupied more than two-folds (58\%), followed by Sundar (27\%) and Limbang (15\%). The medium resolution ALOS data were efficient for mapping dominant mangrove species such as Nypa fruticans, Rhizophora apiculata, Sonneratia caseolaris, S. alba and Xylocarpus granatum in the vicinity (accuracy: 80\%). The PCQM estimates found a higher basal area at Limbang and Menumbok $>$ suggestive of more mature vegetation, compared to Sundar and Weston. Mangrove stand structural complexity (derived from the complexity index) was also high in the order of Limbang > Menumbok > Sundar > Weston and supporting the perspective of less/undisturbed vegetation at two former locations. Both remote sensing and ground-truth observations have complementarily represented the distribution of Sonneratia spp. as pioneer vegetation at shallow river mouths, $N$. fruticans in the areas of strong freshwater discharge, R. apiculata in the areas of strong neritic incursion and X. granatum at interior/elevated grounds. The results from this study would be able to serve as a strong base-line data for future mangrove investigations at Brunei Bay, including for monitoring and management purposes locally at present. 
4 Behara Satyanarayana ${ }^{1,2 \dagger^{*}}$, Aidy M. Muslim ${ }^{1 \dagger^{*}}$, Nurul Amira Izzaty Horsali ${ }^{1}$, Nurul Ashikin Mat 5 Zauki $^{1}$, Viviana Otero ${ }^{2}$, Muhammad Izuan Nadzri ${ }^{1}$, Sulong Ibrahim ${ }^{1}$, Mohd-Lokman Husain ${ }^{1}$ and 6

\section{Status of the undisturbed mangroves at Brunei Bay, East Malaysia: a} preliminary assessment based on remote sensing and ground-truth

\section{observations}

${ }^{1}$ Mangrove Research Unit (MARU), Institute of Oceanography and Environment (INOS), Universiti Malaysia Terengganu (UMT), 21030 Kuala Terengganu, Malaysia.

${ }^{2}$ Laboratory of Systems Ecology and Resource Management, Université Libre de Bruxelles (ULB), CPI 264/1, Avenue Franklin Roosevelt 50, B-1050 Brussels, Belgium.

${ }^{3}$ Laboratory of Plant Biology and Nature Management, Vrije Universiteit Brussel (VUB), Pleinlaan 2, B-1050 Brussels, Belgium.

$\dagger$ Co-first authors of this work

*Corresponding author: satyam2149@gmail.com \& aidy@umt.edu.my

\section{(1)}


23 Brunei Bay - receiving freshwater discharge from the four major rivers namely, Limbang,

24 Sundar, Weston and Menumbok, hosts a luxuriant mangrove cover in East Malaysia. However,

this relatively undisturbed mangrove forest has been less scientifically explored especially in terms of vegetation structure, ecosystem services and functioning, and land-use/cover changes. In the present study, mangrove areal extent together with species composition and distribution at the four notified estuaries was evaluated through remote sensing (Advanced Land Observation Satellite - ALOS) and ground-truth (Point-Centred Quarter Method - PCQM) observations. As of 2010, the total mangrove cover was found to be ca. $35,183.74$ ha, of which Weston and Menumbok occupied more than two-folds (58\%), followed by Sundar (27\%) and Limbang (15\%). The medium resolution ALOS data were efficient for mapping dominant mangrove species such as Nypa fruticans, Rhizophora apiculata, Sonneratia caseolaris, S. alba and Xylocarpus granatum in the vicinity (accuracy: 80\%). The PCQM estimates found a higher basal area at Limbang and Menumbok - suggestive of more mature vegetation, compared to Sundar and Weston. Mangrove stand structural complexity (derived from the complexity index) was also high in the order of Limbang $>$ Menumbok $>$ Sundar $>$ Weston and supporting the perspective of less/undisturbed vegetation at two former locations. Both remote sensing and ground-truth observations have complementarily represented the distribution of Sonneratia spp. as pioneer vegetation at shallow river mouths, $N$. fruticans in the areas of strong freshwater discharge, $R$. apiculata in the areas of strong neritic incursion and $X$. granatum at interior/elevated grounds.

42 The results from this study would be able to serve as a strong base-line data for future mangrove investigations at Brunei Bay, including for monitoring and management purposes locally at present. 


\section{INTRODUCTION}

46 A combination of ground-truth and remote sensing data analysis is advantageous for developing

47 the most reliable land-use/cover mapping and thereby useful to make appropriate decisions for

48

49

50

51

52

53

54

55

56

57

58

59

60

61

62

63

64

65

66

67 conservation and management of the natural resources (Kovacs et al., 2001, 2004; Chauhan \& Dwivedi, 2008; Neukermans et al., 2008; Satyanarayana et al., 2011; Leempoel et al., 2013). In the case of mangroves, remote sensing data have become indispensable due to its time saving and cost-effective nature compensating for the fieldwork, which is often difficult to carry out, especially in areas of low accessibility (Giri et al., 2007; Dahdouh-Guebas \& Koedam, 2008; Giri et al., 2008; Massó i Alemán et al., 2010; Giri et al., 2011; Satyanarayana et al., 2011; Cárdenas, Joyce \& Maier, 2017). Mangrove mapping - as per the target of identifying different vegetation details - has been conducted with low to very high-resolution space-born (e.g. Landsat, IKONOS, QuickBird, GeoEye-1) and air-born remote sensing data (Dahdouh-Guebas et al., 2000; Sulong et al., 2002; Wang et al., 2004; Seto and Fragkias, 2007; Giri et al., 2008; Dahdouh-Guebas \& Koedam, 2008; Spalding, Kainuma \& Collins, 2010; Giri et al., 2011; Hansen \& Loveland, 2012; Leempoel et al., 2013; Proisy et al., 2016). Also, the potential of moderate resolution data like Advanced Land Observation Satellite [ALOS] and Sentinel for mangrove studies is well recognised (Hartoko et al., 2015; Castillo et al., 2017; Chen et al., 2017). The optical remote sensing data which were often limited by cloud cover to study mangrove ecosystems have been compensated through the radar and drone imageries in recent years (Walters et al., 2008; Cornforth et al., 2013; De Santiago, Kovacs \& Lafrance, 2013; Kovacs et al., 2013; Hamdan, Khali Aziz \& Mohd Hasmadi, 2014; Lucas et al., 2014; Jhonnerie et al., 2015; Aslan et al., 2016; Tian et al., 2017). Similarly, there are several plot-based and plotless methods exist for undertaking vegetation inventories (Elzinga et al., 2001). Among others, 
68 the Point-Centred Quarter Method (PCQM) is recognised as the most appropriate ground-truth

69 for mangrove and remote sensing combinatory investigations (Cintron \& Schaeffer Novelli,

70 1984; Dahdouh-Guebas \& Koedam, 2006; Satyanarayana et al., 2011). The PCQM is not only

71 efficient for characterising mangrove vegetation and less time-consuming, but it also causes

72 minimum damage to the understorey while sampling (Cunningham, 2001; Dahdouh-Guebas \&

73 Koedam, 2006).

The mangrove forest in Malaysia (709,700.00 ha) is the second largest in Southeast Asia and sixth (after Indonesia, Brazil, Australia, Mexico and Nigeria) among the nations that supporting highest mangrove cover in the world (Spalding, Kainuma \& Collins, 2010; Hamdan et al., 2012). East Malaysia (i.e. Sabah and Sarawak) is supporting up to $84 \%$ of the country's mangroves and West (Peninsular) Malaysia the remaining 16\% (Table 1). Mangroves at Brunei Bay are jointly shared, but separately administered by East Malaysia and Brunei Darussalam (Figure 1). Although known as one of the largest tracts of relatively undisturbed forest in eastern Asia (FD, 2010), the mangroves at Brunei Bay have been less scientifically explored and much of the information on vegetation structure, ecosystem services and functioning, and landuse/cover changes is confined to grey literature (e.g. Justin, 2007; Ali \& Mohd. Ariff, 2007; NRE, 2014). According to Adiana et al. (2017), there were only five scientific publications between 1968 and 2012 on Brunei Bay, and they related to water pollution and marine mammals in the area. The research works after 2012 (e.g. Alkhadher et al., 2015; Joseph et al., 2016; Proum et al., 2016; Joseph et al., 2017) also focused on sediment pollution and sea turtles, but none were specific to the (Malaysian) mangrove vegetation.

The present study was primarily aimed at identifying the current status of the Malaysian mangrove cover at Brunei Bay. The objectives were to develop a species-level classification map 
91 based on remote sensing (ALOS) data for Limbang, Sundar, Weston and Menumbok estuaries

92 adjoining Brunei Bay, and to integrate and validate the findings through ground-truth (PCQM)

93 observations.

\section{2. MATERIALS AND METHODS}

95

96

97

98

\subsection{Study area}

Brunei Bay is extended over 2,500 $\mathrm{km}^{2}$ where much of its aquatic and terrestrial land belongs to East Malaysia (Figure 1). The bay area is also known as a significant habitat for marine biological diversity in the South China Sea (Vo, Pernetta \& Paterson, 2013; Joseph et al., 2016). The southern limit of the bay is flanked by lush green mangroves, especially on the lower reaches of Limbang, Sundar, Weston and Menumbok rivers (BLI, 2015). The Limbang estuary emerging from the three rivers namely, Sungai Manunggul, Sungai Limbang and Sungai Pandaruan - is orientated in a north-south direction whereas the Sundar estuary - emerging from Sungai Trusan - is stretched between Kuala Trusan and Tanjung Perepat in a west-east direction. Both Weston and Menumbok estuaries are formed by Sungai Padas and Sungai Klias, respectively, and runs in north-east direction. The mangrove vegetation together with seagrass beds and coral reefs in Brunei Bay are providing several eco-socio-economic benefits to the local communities (Ahmad-Kamil et al., 2013). This study was conducted with the permission of the State Forestry Department of Sarawak (\# NCCD.907.4.4 (Jld. 10)-294). regimes: northeast (mid-December to mid-March) and southwest (mid-May to the end of October) (Malik, 2011). The historical weather data (2005-2015) showed an average highest temperature of $33.5^{\circ} \mathrm{C}$ for April-May and the highest precipitation of $72.9 \mathrm{~mm}$ for June (WU, 
113 2015). Intense seawater current, accompanied by strong winds, can be observed every year

114 during the northeast monsoon (Nelson et al., 2015). Monsoonal impact in the areas facing the

115 South China Sea is evident by coastal erosion and, less and patchy distribution of the mangrove

116 cover (Hamdan et al., 2012).

\section{2.2. Remote sensing data and analysis}

118 For mangrove species-level mapping at Brunei Bay, the Advanced Visible and Near-Infrared Radiometer type 2 (AVNIR-2) data acquired from the ALOS (spatial resolution: $10 \mathrm{~m}$ ) (dated 1st September 2010) were used. The ALOS data - subjected to both atmospheric and geometric corrections - were provided by the Japan Science and Technology Agency (JST). However, to

122 ensure a good match of the land-use/cover features in the imagery with the ground-truth observations, the data have been georeferenced again with WGS_1984 coordinate system using a toposheet (1:50 000) obtained from the Department of Survey and Mapping Malaysia (RMS error: 0.682) (ArcMap v.10). In order to have a better image processing and analysis, the mangrove areas adjacent to the bay and river channels were digitised on-screen. For the medium resolution remote sensing data like ALOS, on-screen digitisation through visual interpretation is indeed beneficial to separate mangrove and non-mangrove areas (Kuenzer et al., 2011). In this context, the false colour composite (FCC) (with 4-3-2 band combination) of the ALOS data was used to recognise the mangroves visible in a darker shade than of nearby terrestrial vegetation due to less spectral reflectance (Spalding, Kainuma \& Collins, 2010; Zhang et al., 2017). The polygon features, as a new shapefile (with WGS_1984 coordinate system), were created only for mangroves under the jurisdiction of East Malaysia, and extracted the raster cells using spatial analyst tools (with 'extract by polygon' function in ArcMap v.10). 
carried out through the maximum-likelihood algorithm that known to facilitate a robust

137

138

139

140

141

142

143

144

145

146

147

148

149

150

151

152

153

154

155

156

157

classification for mangroves (Wang, Sousa \& Gong, 2004; Shafri, Suhaili \& Mansor, 2007;

Satyanarayana et al., 2011; Kuenzer et al., 2011; Nguyen et al., 2013; Khatami, Mountrakis \& Stehman, 2016; Mafi-Gholami, Mahmoudi \& Zenner, 2017). In this context, the training samples for the most dominant mangrove taxa such as Nypa, Rhizophora, Sonneratia and Xylocarpus spp., were assigned based on ground knowledge acquired through the PCQM (68 sample points: Limbang - 9, Sundar - 19, Weston - 20 and Menumbok - 20) (details are given in $§ 2.3$ ). In addition, tonality and textural characteristics (in FCC) of the dominant species were considered (cf. Dahdouh-Guebas et al., 2000; NRC, 2006). For instance, Nypa vegetation was represented by a dark red colour with coarse texture, whereas Rhizophora by bright red with fine texture, Sonneratia by light red with open spaces (especially at river mouths), and Xylocarpus by a bright red colour with coarse texture (especially at back mangrove area). Based on our ground knowledge and visual interpretation of the satellite data, we assigned 20-25 training samples (with a pixel count of 125,135-572,692) for the widespread mangrove species (Nypa, Rhizophora spp.), and 10-15 (with a pixel count of 98,610-102,029) for the locally distributed species (Sonneratia, Xylocarpus spp.). The classified image was then subjected to an accuracy assessment through a confusion matrix (Congalton, 1991), for which 144 additional ground control points (GCPs) (Limbang - 60, Sundar - 45, Weston - 26 and Menumbok - 13) collected from both mangrove and non-mangrove areas were used. The GCPs were collected randomly as per the forest condition and accessibility. The location of the GCPs was marked on the ALOS imagery (hardcopy) and recorded the type of land-use/cover (i.e. mangrove or non-mangrove), together with species composition in the case of mangrove, for the accuracy assessment. Most 
158 locations in mangrove from where the GCPs were collected have shown the distribution of

159 dominant species in more than $10 \mathrm{~m} \times 10 \mathrm{~m}$ land-cover area.

160

For the accuracy assessment, we also report quantity $(\%)$ - the amount of pixels that

161 differed between reference data and classification per class, exchange (\%) - the allocated error

162 by number of pixels that interchanged between two classes, and shift (\%) - the other allocation

163 differences that were not included in the exchange difference (cf. Pontius \& Millones, 2011;

164 Pontius \& Santacruz, 2014). Any disagreements among quantity, exchange and shift variables

165 are useful to learn the sources of error in the classification in a more interpretable manner

166 (Pontius \& Millones, 2011). Estimates of quantity, exchange and shift were made from the

167 PontiusMatrix41 (Microsoft Excel file) developed by R.G. Pontius

168 (https://www.clarku.edu/ rpontius/).

Area statistics showing the total mangrove cover (with a species-level demarcation for each estuary) at Brunei Bay were derived from the supervised classification. For this purpose, the mangrove extent was treated under three sectors: Limbang, Sundar (up to Sipitang village) and

172 Weston + Menumbok together (due to no clear-cut mangrove boundary between these two 173 estuaries). However, there were a few limitations identified with the ALOS data. Firstly, the 174 image was four years old at the time of fieldwork. Second, a (minor) patch of mangrove was 175 missing on the northern most corner of Menumbok (Figure 1). The former concern was 176 evaluated through our ground inventory by observing the mangrove cover changes (if any), while 177 the latter was identified from Google Earth Pro (image dated 29th November 2014) by digitising 178 the missing (mangrove) area.

\subsection{Ground inventory}


180 For the ground data collection (5th-19th August 2014), two $100 \mathrm{~m}$ length transects - one close

181 to the river mouth and another in mid-forest - were chosen from each estuary i.e., Limbang,

182 Sundar, Weston and Menumbok (eight transects in total). Sampling at the river mouth was

183 chosen to identify the pioneer group of vegetation (i.e. mangrove succession by select species),

184 whereas in the mid-forest to identify other available species in the vicinity. We took a $100 \mathrm{~m}$

185 transect in order to cover at least ten sample points with 4 quadrants of the PCQM (cf.

186 Satyanarayana et al., 2002; Engeman et al., 2004; Satyanarayana et al., 2011). Different adult

187 tree (i.e. $\geq 1.3 \mathrm{~m}$ height with a diameter $\left(\mathrm{D}_{130}\right)$ of $\geq 2.5 \mathrm{~cm}$ or girth $\left.\left(\mathrm{G}_{130}\right) \geq 8 \mathrm{~cm}\right)$ structural

188 parameters such as density (trees $\left.0.1 \mathrm{ha}^{-1}\right)$, basal area $\left(\mathrm{m}^{2} 0.1 \mathrm{ha}^{-1}\right)$, relative density $(\%)$, relative 189 dominance (\%), relative frequency (\%), species' importance value (IV) (relative density + 190 relative dominance + relative frequency), and the complexity index (CI) were estimated using the 191 P-DATA PRO v. 5.01 interface developed by Dahdouh-Guebas \& Koedam (2006). In the case of 192 Nypa - as its stem remains underground - the diameter of all leaf shoots was considered to 193 determine the (average) basal area. For mangrove species identification, the nomenclature 194 suggested by Tomlinson (1986) and Duke (2006) was followed. Each tree height was measured 195 with the help of a clinometer (Suunto PM-5, Finland). A hand-held Global Positioning System 196 (Garmin 45, Olathe, KS, USA) was used for navigation and to obtain the latitude and longitude 197 positions of the sampling points.

\subsection{Statistical analysis}

199 Variation between the tree structural parameters, like density and basal area, at Limbang, Sundar, 200 Weston and Menumbok estuaries was tested through one-way ANOVA (OriginPro v. 9.1).

\section{RESULTS}


202

203

204

205

206

207

208

209

210

211

212

213

214

215

216

217

218

219

220

221

222

223

\subsection{Remote sensing based observations}

From the supervised classification of the ALOS data (Figure 2), it was possible to recognise the predominance of Sonneratia caseolaris (L.) Engler, Rhizophora apiculata B1. and Nypa fruticans (Thunb.) Wurmb., along with S. alba J. Smith and Xylocarpus granatum König species at Brunei Bay (accuracy: 80\% and Kappa index: 0.714) (Table 2). The difference in the amount of pixels between the reference data and the classification per class (= quantity) was found to be $9 \%$, whereas the error due to interchanged pixels between two classes (= exchange) was $7 \%$ and the allocation difference other than to the exchange difference $(=s h i f t)$ was $1 \%$. Among the five mangrove species, $N$. fruticans showed the highest quantity (9\%) and exchange (7\%) differences (Figure 3). In fact, there was a considerable overlap in the (visible range) spectral reflectance values of the dominant mangrove species (Figure 4). The Malaysian mangrove cover at Brunei Bay was found to be $c a$. 35,183.74 ha of which Limbang occupied 5,011.42 ha, Sundar (up to Sipitang village) 9,606.46 ha, and Weston + Menumbok 20,565.86 ha (Table 3). If the spatial extent of each mangrove species is considered, $N$. fruticans shows a widespread distribution $(14,879.27 \mathrm{ha})$, followed by $R$. apiculata (12,801.89 ha), S. caseolaris $(5,533.10 \mathrm{ha}), X$.

granatum (993.10 ha) and S. alba (976.38 ha) (Table 3). Area-wise, Limbang, Weston and Menumbok were dominated by $N$. fruticans (as an important species), and Sundar by $R$. apiculata (Table 3).

\subsection{Ground inventory observations}

Ground-truth observations found several non-dominant mangrove species like Avicennia alba Blume, Bruguiera gymnorrhiza (L.) Lamk., B. cylindrica (L.) Blume, Ceriops sp., Heritiera littoralis Dryand and Kandelia candel (L.) Druce, along with the associates such as Acanthus 
224 ilicifolius L., Acrostichum aureum L., Derris trifoliata Lour. and Hibiscus tilliaceus L., in the 225 vicinity. Out of 11 dominant and non-dominant mangrove species, only nine were encountered in 226 the vegetation (PCQM) sampling points (Table 4). Among the four estuaries, Limbang had the 227 highest mangrove basal area $\left(120.17 \mathrm{~m}^{2} 0.1 \mathrm{ha}^{-1}\right.$ with a density of 163 trees $\left.0.1 \mathrm{ha}^{-1}\right)$, followed 228 by Menumbok $\left(81.17 \mathrm{~m}^{2} 0.1 \mathrm{ha}^{-1}\right.$ with a density of 132 trees $\left.0.1 \mathrm{ha}^{-1}\right)$, Weston $\left(35.10 \mathrm{~m}^{2} 0.1 \mathrm{ha}^{-1}\right.$ 229 with a density of 130 trees $\left.0.1 \mathrm{ha}^{-1}\right)$, and Sundar $\left(33.24 \mathrm{~m}^{2} 0.1 \mathrm{ha}^{-1}\right.$ with a density of 134 trees 0.1 $230 \mathrm{ha}^{-1}$ ). Basal area at Limbang and Menumbok was significantly different from Sundar and Weston 231 (one-way ANOVA, $P=0.08$ ). Sonneratia caseolaris holds the highest importance value for 232 Limbang, while R. apiculata for both Sundar and Menumbok, and N. fruticans for Weston. The

mangrove stand structural complexity (derived from the complexity index) was high in the order of Limbang $>$ Menumbok $>$ Sundar $>$ Weston (Table 4). In terms of the diameter class distribution, more than $50 \%$ of trees at Limbang were represented by $31-90 \mathrm{~cm}$ (range: 9.5-198.9 cm), Sundar 2.5-40 cm (range: 3.2-186.1 cm), Weston 2.5-60 cm (range: 3.0-190.1 $\mathrm{cm}$ ), and Menumbok 2.5-120 cm (range: 2.5-250 cm) (Figure 5).

The ground inventory also revealed no detectable changes in relation to the four-year old satellite (ALOS) data. The core mangroves were found intact in almost all locations between 2010 and 2014. The only sign of change was observed at Limbang, Sundar and Weston river mouths where shrubby vegetation (as understood from the visual interpretation of the ALOS data before the fieldwork) had become grown-up Sonneratia trees (height: 9-13 m). The missing mangrove patch (observed from the Google Earth) on the northern most corner of Menumbok was $c a .3,741$ ha and found to be co-dominated by $R$. apiculata and $N$. fruticans (similar to other mangrove patches at Menumbok). 


\section{DISCUSSION}

247 In recent years, remote sensing technology has greatly enhanced our understanding of mangrove

248 ecosystems (Walcker, Gratiot \& Anthony, 2016). The present study also found several

249 interesting observations about the Malaysian mangrove cover at Brunei Bay. As of 1st

250 September 2010 (ALOS data), the spatial extent of the mangroves was 35,183.74 ha (Figure 2

251 and Table 3). However, if the missing mangrove patch of 3,741 ha is considered then the total

252 mangrove cover should be ca. 38,924.74 ha. The ALOS data were efficient for mapping

253 dominant mangrove species in the study area. Earlier, Hamdan, Khali Aziz and Mohd Hasmadi

254 (2014) have used the ALOS data for identifying above ground biomass of the Matang Mangrove

255 Forest Reserve (in Peninsular Malaysia) and found it advantageous to assess the vegetation

256 across larger areas. The noise observed in the present supervised classification was chiefly

257 associated with misclassification in-between $R$. apiculata, S. caseolaris and $N$. fruticans species.

258 Differences in both quantity and exchange indicate that the area covered by $N$. fruticans was

259 slightly underestimated due to $R$. apiculata and S. caseolaris interference in some locations

260 (Figure 6A-B). Perhaps further understanding on the spectral reflectance properties of Nypa,

261 Rhizophora and Sonnertia spp., would be able to improve the classification accuracy. In

262 addition, application of the nonparametric algorithms like decision-tree could become

263 advantageous for future mangrove mapping attempts (Zhang et al., 2017). The freely available

264 moderate resolution satellite data (e.g. Sentinel) be a chance to correspond with the dates of

265 ground inventory. On the other hand, pinpoint discrimination of the vegetation species, mixed

266 with different age groups (juvenile, young and adult), is not practicable through the use of

267 remote sensing data (Xie, Sha \& Yu, 2008). 

patterns reported elsewhere. For example, succession by Sonneratia spp. at Limbang, Sundar and Weston river mouths indicates their pioneering nature along the open coasts on silty and siltysand substrates (Figure 6C) (Satyanarayana et al., 2002; FAO, 2007; Satyanarayana et al., 2010). However, S. caseolaris is also known to colonise the elevated (upstream) grounds (Saenger, 2002), and this could be a reason for its inland occurrence at Brunei Bay. According to Nik Nurizni (2015), the varying surface water salinity between $7.2-19.3 \%$ and $0.6-21.3 \%$ at the

275 downstream locations of Limbang (depth: $1.8 \mathrm{~m}$ ) and Sundar (depth: $2.5 \mathrm{~m}$ ) shows a considerable freshwater discharge in both areas (no water quality measurements are available for Weston). In contrast, the lower abundance of Sonneratia spp. at Menumbok river mouth as well as upstream areas could be linked to the lack of sediment accretion grounds (Figure 2) and deep water channels (depth: $4.6 \mathrm{~m}$ and salinity: 22.8-27.9 \%o) (Nik Nurizni, 2015). The species like Nypa fruticans that inhabit on soft and fine-grained substrates in the areas of strong freshwater discharge and $R$. apiculata in the areas of strong neritic incursion (cf. Tomlinson, 1986; Saenger, 2002; Teh et al., 2008; Satyanarayana et al., 2010) have shown their widespread distribution at Brunei Bay, whereas $X$. granatum is confined to the interior and elevated grounds (cf. Satyanarayana et al., 2002, 2009). the vegetation status, but also for monitoring/management through the silvicultural practices (Dahdouh-Guebas \& Koedam, 2006). Among others, basal area represents wood volume and is beneficial to assess any vegetation in terms of its succession or maturation (Satyanarayana et al., 2002, 2009, 2010). At Brunei Bay, higher basal area at Limbang and Menumbok shows more matured nature of the trees as opposed to Sundar and Weston (Table 4). While the majority of 
291 trees with a diameter of 31-90 cm have contributed to the highest basal area at Limbang, the 292 trees with a 2.5-120 cm diameter were responsible for Menumbok. Diameter limited to $60 \mathrm{~cm}$ 293 and less for a greater number of trees catered lower basal area for Sundar and Weston (Figure 5).

294 The complexity index, that depends largely on density, basal area and tree height estimates 295 (Holdridge et al., 1971), could represent less/undisturbed nature of the vegetation along with its 296 potential contribution to the biodiversity at both Limbang and Menumbok (cf. Parkes, Newell \& 297 Cheal, 2003; Kovalenko, Thomaz \& Warfe, 2012; Bartholomew, Hafezi \& Karimi, 2016; 298 Tongway and Ludwig, 2011). The geographic location of Sundar and Weston which is rather 299 under the direct influence of bay waters must be accountable for its less structural complexity. 300 The mangroves here seemed to be experiencing a stressful environment due to surplus 301 inundation, flood and ebb water current, etc., which in turn causing some trees to uproot (Figure 302 6D-E). It should be noticed that mangrove establishment and growth attains better along 303 sheltered coastlines than to the open areas (Alongi, 2008). The differences - in terms of important mangrove species at each estuary - between 305 remote sensing and vegetation survey are understandable as the supervised classification provide details of the entire mangrove cover (Table 3) whereas the PCQM provide details of the two 307 transect-based observations (Table 4). In fact, both ground-truth and remote sensing results were 308 virtually complementing each other at the places of vegetation inventory (Figure 2). However, we draw the attention to the preliminary nature of our study, emphasizing the need for longer transects and more sample points in multiple homogeneous mangrove patches (cf. Engeman et al., 1994; Dahdouh-Guebas \& Koedam, 2006) to estimate the forest structural parameters with

312 higher accuracy. In view of recent literature it might also be more interesting to measure the 313 second or third nearest tree when applying PCQM (cf. Hijbeek et al., 2014; Khan et al., 2016). 

studies at Brunei Bay due to poor scientific literature. Also, our efforts to find the actual (Brunei Bay) mangrove area from Sabah and Sarawak Forestry Departments did not yield satisfactory results. Though Sabah Forestry Department has informed the mangrove cover at Weston and Menumbok as 14,932 ha (pers. comm., 14th February 2016), but this figure was different from the present observation i.e., 24,306.86 ha $(20,565.86$ ha [ALOS-based] $+3,741$ ha [Googlebased]). The main reason for this difference was due to 'state land' and 'forest land' categories of mangrove vegetation at Brunei Bay (Forestry Department do not consider the state land forest). Therefore, the present study (with dendrometric measurements and species-level mapping) is able to serve as a strong base-line data for future mangrove investigations at Brunei Bay, including for monitoring and management purposes locally at present.

\section{CONCLUSIONS}

Malaysian mangrove cover at Brunei Bay - from Limbang, Sundar, Weston and Menumbok estuaries - was evaluated for the first four by means of scientific measures invoking remote sensing (ALOS) and ground-truth (PCQM) data. Moderate resolution of the ALOS data was efficient for mapping dominant mangrove species in the vicinity. Spatial extent of the dominant mangroves was estimated at $c a .35,183.74$ ha where $N$. fruticans occupied the highest land-cover inventory revealed the abundance of $N$. fruticans and $R$. apiculata as widespread species while $S$. caseolaris, X. granatum and $S$. alba as locally distributed species at the river mouth and/or interior/elevated grounds. The other less dominant species such as A. alba, B. gymnorrhiza, $B$. cylindrica and Ceriops sp. contributed insignificantly to the vegetation structure. High basal area at Limbang and Menumbok represents more matured nature of the vegetation as comparted to 
337 Sundar and Weston. Geographic location facing the direct influence of bay waters, surplus

338 inundation, and flood and ebb water current were some of the issues believed to be responsible

339 for low basal area and less mature vegetation at Sundar and Weston. Further understanding on

340 the spectral reflectance properties of the co-dominant Nypa, Rhizophora and Sonnertia spp.,

341 along with application of the nonparametric algorithms like decision-tree, would be able to

342 improve the accuracy of mangrove land-cover mapping. Overall, both remote sensing and

343 ground-truth observations are in a general agreement to represent the (dominant) mangrove

344 species composition and distribution at Brunei Bay and be able serve as a strong base-line data

345 for future investigations.

\section{ACKNOWLEDGEMENTS}

348 The ALOS satellite data was provided by the JST under the Ocean Remote Sensing Project of 349 the WESTPAC. Authors are grateful to administrative authorities at the JST and the UMT. 350 Special thanks go to Mr. Subarjo and Mr. Kamal - the Science Officers at the INOS - for their

351 kind support in the fieldwork. The courtesies extended by Mr. Ismail and his family at Lawas are 352 greatly appreciated. Help rendered by the UMT undergraduate students - Nik Nurizni Nik Ali,

353 Nooratikah Binti Mohd Din, Wajihah Binti Mat Nawi, and Rafidah Binti Abd Wahab - was 354 invaluable. 
358

359

360

361

362

363

364

365

366

367

368

369

370

371

372

373

374

375

376

377

\section{REFERENCES}

Adiana G, Juahir H, Joseph B, Shazili NAM. 2017. Tracing the sources of lead $(\mathrm{Pb})$ in Brunei Bay, Borneo by using integrated spectrometry ICP-MS and chemometric techniques. Marine Pollution Bulletin 123: 232-240.

Ahmad-Kamil EI, Ramli R, Jaaman SA, Bali J, Al-Obaidi JR. 2013. The effects of water parameters on monthly seagrass percentage cover in Lawas, East Malaysia. The Scientific World Journal ID 892746. Available at http://dx.doi.org/10.1155/2013/892746 (accessed 8th May 2015).

Ali I, Mohd. Ariff MR. 2007. The relationship of marine coastal ecosystem and river estuaries with the socioeconomic community of fishermen in Brunei Bay and Padas Bay, Sabah: a survey. Jati 12: 229-245.

Alkhadher SAA, Zakaria MP, Md Yusoff F, Kannan N, Suratman S, Keshavarzifard M, Magam SM, Masood N, Vaezzadeh V, Sani MSA. 2015. Baseline distribution and sources of linear alkyl benzenes (LABs) in surface sediments from Brunei Bay, Brunei. Marine Pollution Bulletin 101: 397-403.

Alongi DM. 2008. Mangrove forests: Resilience, protection from tsunamis, and responses to global climate change. Estuarine, Coastal and Shelf Science 76: 1-13.

Aslan A, Rahman AF, Warren MW, Robeson SM. 2016. Mapping spatial distribution and biomass of coastal wetland vegetation in Indonesian Papua by combining active and passive remotely sensed data. Remote Sensing of Environment 183: 65-81. 
378 Bartholomew A, Hafezi SA, Karimi S. 2016. Effects of habitat complexity on the abundance,

379 species richness and size of darkling beetles (Tenebrionidae) in artificial vegetation. Journal of Arid Environments 129: 35-41.

381

382

383

384

385

386

BLI (BirdLife International). 2015. Important bird and biodiversity areas (IBAs) - Brunei Bay (Malaysia). Available at http://www.birdlife.org (accessed 14 May 2015).

Cárdenas NY, Joyce KE, Maier SW. 2017. Monitoring mangrove forests: are we taking full advantage of technology? International Journal of Applied Earth Observation and Geoinformation 63: 1-14.

Castillo JAA, Apan AA, Maraseni TN, Salmo III SG. 2017. Estimation and mapping of aboveground biomass of mangrove forests and their replacement land uses in the Philippines using Sentinel imagery. ISPRS Journal of Photogrammetry and Remote Sensing 134: 70-85.

Chauhan HB, Dwivedi RM. 2008. Inter sensor comparison between RESOURCESAT LISS III, LISS IV and AWiFS with reference to coastal landuse/landcover studies. International Journal of Applied Earth Observation and Geoinformation 10: 181-185.

Chen B, Xiao X, Li X, Pan L, Doughty R, Ma J, Dong J, Qin Y, Zhao B, Wu Z, Sun R, Lan G, Xie G, Clinton N, Giri C. 2017. A mangrove forest map of China in 2015: analysis of time series Landsat 7/8 and Sentinel-1A imagery in Google Earth Engine cloud computing platform. ISPRS Journal of Photogrammetry and Remote Sensing 131: 104-120.

Cintrón G, Schaeffer Novelli Y. 1984. Methods for studying mangrove structure. In: Snedaker $\mathrm{SC}$, Snedaker JG eds. The mangrove ecosystem: research methods. Paris: UNESCO, $91-113$. 
399 Congalton RG. 1991. A review of assessing the accuracy of classifications of remotely sensed 400 data. Remote Sensing of Environment 37:35-46.

401 Cornforth WA, Fatoyinbo TE, Freemantle TP, Pettorelli N. 2013. Advanced Land Observing 402 Satellite Phased Array Type L-Band SAR (ALOS PALSAR) to inform the conservation of 403 mangroves: Sundarbans as a case study. Remote Sensing 5: 224-237.

Cunningham AB. 2001. Applied ethnobotany: people, wild plant use and conservation. London: Earthscan Publications Limited.

406

407

408

409

410

411

412

413

414

415

416

417

Dahdouh-Guebas F, Koedam N. 2006. Empirical estimate of the reliability of the use of the Point-Centred Quarter Method (PCQM): solutions to ambiguous field situations and description of the PCQM+ protocol. Forest Ecology and Management 228: 1-18.

Dahdouh-Guebas F, Koedam N. 2008. Long-term retrospection on mangrove development using transdisciplinary approaches: a review. Aquatic Botany 89: 80-92.

Dahdouh-Guebas F, Verheyden A, De Genst W, Hettiarachchi S, Koedam N. 2000. Four decades vegetation dynamics in Sri Lankan mangroves as detected from sequentialaerial photography: a case study in Galle. Bulletin of Marine Science 67: 741-759.

De Santiago FF, Kovacs JM, Lafrance P. 2013. An object-oriented classification method for mapping mangroves in Guinea, West Africa, using multipolarized ALOS PALSAR Lband data. International Journal of Remote Sensing 34: 563-586.

Duke NC. 2006. Australia's mangroves. Brisbane: University of Queensland. 
418 Elzinga CL, Salzer DW, Willoughby JW, Gibbs JP. 2001. Monitoring plant and animal 419 populations. Massachusetts: Blackwell Science.

420

421

422

423

424

425

426

427

428

429

430

431

432

433

434

435

436

Engeman RM, Sugihara RT, Pank LF, Dusenberry WE. 1994. A comparison of plotless density estimators using Monte Carlo simulation. Ecology 75: 1769-1779.

FAO (Food and Agriculture Organization). 2007. Mangrove guide book for South and Southeast Asia (RAP/2006/07). Bangkok: Dharmasarn Co., Ltd.

FD (Forestry Department). 2010. $4^{\text {th }}$ National report to the convention on biological diversity, Brunei Darussalam. Available at https://www.cbd.int/reports/ (accessed 26th May 2015).

Giri C, Pengra B, Zhu Z, Singh A, Tieszen L-L. 2007. Monitoring mangrove forest dynamics of the Sundarbans in Bangladesh and India using multi-temporal satellite data from 1973 to 2000. Estuarine, Coastal and Shelf Science 73: 91-100.

Giri C, Zhu Z, Tieszen LL, Singh A, Gillette S, Kelmelis JA. 2008. Mangrove forest distributions and dynamics (1975-2005) of the tsunami-affected region of Asia. Journal of Biogeography 35: 519-528.

Giri C, Ochieng E, Tieszen LL, Zhu Z, Singh A, Loveland T, Masek J, Duke NC. 2011. Status and distribution of mangrove forests of the world using earth observation satellite data. Global Ecology and Biogeography 20: 154-159.

Hamdan O, Khali Aziz H, Shamsudin I, Raja Barizan RS. 2012. Status of mangroves in Peninsular Malaysia. Kuala Lumpur: Forestry Department Peninsular Malaysia. 
437 Hamdan O, Khali Aziz H, Mohd Hasmadi I. 2014. L-band ALOS PALSAR for biomass 438 estimation of Matang Mangroves, Malaysia. Remote Sensing of Environment 155: 69-78.

439 Hansen MC, Loveland TR. 2012. Remote Sensing of Environment: a review of large area $440 \quad$ monitoring of land cover change using Landsat data. Remote Sensing of Environment 122: $441 \quad 66-74$.

442 Hartoko A, Chayaningrum S, Febrianti DA, Ariyanto D, Suryanti. 2015. Carbon biomass 443 algorithms development for mangrove vegetation in Kemujan, Parang Island Karimunjawa 444

Hijbeek R, Koedam N, Khan MNI, Kairo JG, Schoukens J, Dahdouh-Guebas F. 2013. An National Park and Demak coastal area - Indonesia. Procedia Environmental Sciences 23:

Holdridge L, Grenke WC, Hatheway WH, Liang T, Tosi JA. 1971. Forest environment in 450 tropical life zones: a pilot study. New York: Pergamon Press.

451

452

453

454 455

456 evaluation of plotless sampling using vegetation simulations and field data from a mangrove forest. PLOS ONE 8: e67201.

Jhonnerie R, Siregar VP, Nababan B, Prasetyo LB, Wouthuyzen S. 2015. Random forest classification for mangrove land cover mapping using Landsat 5 TM and ALOS PALSAR imageries. Procedia Environmental Sciences 24: 215-221.

Joseph J, Nishizawa H, Arshaad WM, Kadir SAS, Jaaman SA, Bali J, Jamaludin NA, Katoh M. 2016. Genetic stock compositions and natal origin of green turtle (Chelonia mydas) foraging at Brunei Bay. Global Ecology and Conservation 6: 16-24. 
457 Joseph J, Nishizawa H, Hassan M, Zakariah MI, Jaaman SA, Xuelei Z. 2017. Utilization of 458 Brunei Bay (Malaysia) as a developmental and foraging habitat for hawksbill turtle 459 (Eretmochelys imbricata). Regional Studies in Marine Science 16: 304-307.

460 Justin SR. 2007. Surface and core sediment characteristics of mangrove in tidal dominated 461 estuaries: Brunei Bay, Sabah. B.Sc. Thesis, University Malaysia Sabah.

462

463

464

465

466

467

468

469

470

471

472

473

474

475

476

Khan MNI, Hijbeek R, Berger U, Koedam N, Grueters U, Zahirul Islam SM, Md Asadul Hasan, Dahdouh-Guebas F. 2016. An evaluation of the plant density estimator the Point-Centred Quarter Method (PCQM) using Monte Carlo simulation. PLoS ONE 11: e0157985.

Khatami R, Mountrakis G, Stehman SV. 2016. A meta-analysis of remote sensing research on supervised pixel-based land-cover image classification processes: general guidelines for practitioners and future research. Remote Sensing of Environment 177: 89-100.

Kovacs JM, Wang J, Blanco-Correa M. 2001. Mapping disturbances in a mangrove forest using multi-date Landsat TM imagery. Environmental Management 27:763-776.

Kovacs JM, Flores-Verdugo F, Wang J, Aspden LP. 2004. Estimating leaf area index of a degraded mangrove forest using high spatial resolution satellite data. Aquatic Botany 80: 13-22.

Kovacs JM, Lu XX, Flores-Verdugo F, Zhang C, Flores de Santiago F, Jiao X. 2013. Applications of ALOS PALSAR for monitoring biophysical parameters of a degraded black mangrove (Avicennia germinans) forest. ISPRS Journal of Photogrammetry and Remote Sensing 82: 102-111. 
477 Kovalenko K, Thomaz S, Warfe D. 2012. Habitat complexity: approaches and future directions. $478 \quad$ Hydrobiologia 685: 1-17.

479 Kuenzer C, Bluemel A, Gebhardt S, Vo Quoc T, Dech S. 2011. Remote sensing of mangrove $480 \quad$ ecosystems: a review. Remote Sensing 3: 878-928.

481 Leempoel K, Satyanarayana B, Bourgeois C, Zhang J, Chen M, Wang J, Bogaert J, Dahdouh482 Guebas F. 2013. Dynamics in mangroves assessed by high-resolution and multi-temporal 483 satellite data: a case study in Zhanjiang Mangrove National Nature Reserve (ZMNNR), P.R. China. Biogeosciences 10: 5681-5689.

Lucas R, Rebelo L-M, Fatoyinbo L, Rosenqvist A, Itoh T, Shimada M, Simard M, Souza-Filho PW, Thomas N, Trettin C, Accad A, Carreiras J, Hilarides L. 2014. Contribution of L-band SAR to systematic global mangrove monitoring. Marine and Freshwater Research 65: 589-603.

Mafi-Gholami D, Mahmoudi B, Zenner EK. 2017. An analysis of the relationship between drought events and mangrove changes along the northern coasts of the Persian Gulf and Oman Sea. Estuarine, Coastal and Shelf Science 199: 141-151.

Malik AQ. 2011. Assessment of the potential of renewables for Brunei Darussalam. Renewable and Sustainable Energy Reviews 15: 427-437.

Massó i Alemán S, Bourgeois C, Appeltans W, Vanhoorne B, De Hauwere N, Stoffelen P, Heaghebaert A, Dahdouh-Guebas F. 2010. The mangrove reference database and herbarium. Plant Ecoloy and Evolution 143:225-232. 
497 NRC (Natural Resources Canada). 2006. Fundamentals of remote sensing: a Canada Centre for 498 Mapping and Earth Observation Tutorial. Available at http://www.nrcan.gc.ca/earthsciences/geography-boundary/remote-sensing/fundamentals/1430 (1st August 2014).

500

501

502

503

504

505

506

507

508

509

510

511

512

513

514

515

516

NRE (Ministry of Natural Resources and Environment). 2014. $5^{\text {th }}$ National report to the convention on biological diversity, Malaysia. Available at https://www.cbd.int/reports/ (27th May 2015).

Nelson BR, Satyanarayana B, Zhong JMH, Shaharom F, Sukumaran M, Chatterji A. 2015. Episodic human activities and seasonal impacts on the Tachypleus gigas (Müller, 1795) population at Tanjung Selangor in Peninsular Malaysia. Estuarine, Coastal and Shelf Science 164: 313-323.

Neukermans G, Dahdouh-Guebas F, Kairo JG, Koedam N. 2008. Mangrove species and stand mapping in Gazi Bay (Kenya) using QuickBird satellite imagery. Journal of Spatial Science 53: $75-86$.

Nguyen HH, McAlpine C, Pullar D, Johansen K, Duke NC. 2013. The relationship of spatialtemporal changes in fringe mangrove extent and adjacent land-use: case study of Kien Giang coast, Vietnam. Ocean \& Coastal Management 76: 12-22.

Nik Nurizni NA. 2015. Water quality in relation to flood and ebb tide conditions inside the mangrove channels at Brunei Bay. B.Sc. Thesis, Universiti Malaysia Terengganu.

Parkes D, Newell G, Cheal D. 2003. Assessing the quality of native vegetation: the 'habitat hectares' approach. Ecological Management \& Restoration 4: S29-S38. 
517 Pontius Jr. RG, Millones M. 2011. Death to Kappa: birth of quantity disagreement and allocation

518 disagreement for accuracy assessment. International Journal of Remote Sensing 32:

$519 \quad 4407-4429$.

520 Pontius Jr. RG, Santacruz A. 2014. Quantity, exchange, and shift components of difference in a 521 square contingency table. International Journal of Remote Sensing 35:7543-7554.

522 Proisy C, Féret J-B, Lauret N, Gastellu-Etchegorry J-P. 2016. Mangrove forest dynamics using 523 very high spatial resolution optical remote sensing. Land Surface Remote Sensing in Urban $524 \quad$ and Coastal Areas 269-295.

525 Proum S, Santos JH, Lim LH, Marshall DJ. 2016. Metal accumulation in the tissues and shells of 526 Indothais gradata snails inhabiting soft and hard substrata in an acidified tropical estuary 527 (Brunei, South East Asia). Regional Studies in Marine Science 8: 487-497.

528 Saenger P. 2002. Mangrove ecology, silviculture and conservation. London: Kluwer Academic 529 Publishers.

530 Satyanarayana B, Raman AV, Dehairs F, Kalavati C, Chandramohan P. 2002. Mangrove floristic 531 and zonation patterns of Coringa, Kakinada Bay, East Coast of India. Wetlands Ecology and 532 Management 10: 25-39.

533 Satyanarayana B, Raman AV, Mohd-Lokman H, Dehairs F, Sharma VS, Dahdouh-Guebas F. 534 2009. Multivariate methods distinguishing mangrove community structure of Coringa in the 535 Godavari Delta, East coast of India. Aquatic Ecosystem Health \& Management 12: 401-408.

536 Satyanarayana B, Idris IF, Mohamad KA, Mohd-Lokman H, Shazili NAM, Dahdouh-Guebas F. 537 2010. Mangrove species distribution and abundance in relation to local environmental 
538

539

540

541

542

543

544

545

546

547

548

549

550

551

552

553

554

555

556

557

settings: a case-study at Tumpat, Kelantan Delta, east coast of peninsular Malaysia. Botanica Marina 53: 79-88.

Satyanarayana B, Mohamad KA, Idris IF, Mohd-Lokman H, Dahdouh-Guebas F. 2011. Assessment of mangrove vegetation based on remote sensing and ground-truth measurements at Tumpat, Kelantan Delta, East Coast of Peninsular Malaysia. International Journal of Remote Sensing 32: 1635-1650.

Seto KC, Fragkias M. 2007. Mangrove conversion and aquaculture development in Vietnam: a remote sensing-based approach for evaluating the Ramsar Convention on Wetlands. Global Environmental Change 17: 486-500.

Shafri HZM, Suhaili A, Mansor IS. 2007. The performance of maximum likelihood, spectral angle mapper, neural network and decision tree classifiers in hyperspectral image analysis. Journal of Computer Science 3: 419-423.

Spalding M, Kainuma M, Collins L. 2010. World Atlas of Mangroves. London: Earthscan Publications Limited.

Sulong I, Mohd-Lokman H, Mohd-Tarmizi K, Ismail A. 2002. Mangrove mapping using LANDSAT imagery and aerial photographs: Kemaman District, Terengganu, Malaysia. Environment, Development and Sustainability 4: 135-152.

Teh SY, DeAngelis DL, Sternberg LSL, Miralles-Wilhelm FR, Smith TJIII, Koh H-L. 2008. A simulation model for projecting changes in salinity concentrations and species dominance in the coastal margin habitats of the Everglades. Ecological Modelling 213: 245-256. 
558 Tian J, Wang L, Li X, Gong H, Shi C, Zhong R. 2017. Comparison of UAV and WorldView-2

559 imagery for mapping leaf area index of mangrove forest. International Journal of Applied $560 \quad$ Earth Observation and Geoinformatics 61: 22-31.

561 Tomlinson PB. 1986. The Botany of Mangroves. New York: Cambridge University Press.

562 Tongway DJ, Ludwig JA. 2011. Vegetation assessments: structure and habitat complexity 563 indicators. In: Restoring disturbed landscapes; putting principles into practice. $564 \quad$ Washington DC: Island Press, 157-162.

565 Vo ST, Pernetta JC, Paterson CJ. 2013. Status and trends in coastal habitats of the South China $566 \quad$ Sea. Ocean \& Coastal Management 85:153-163.

567 Walcker R, Gratiot N, Anthony EJ. 2016. Remote sensing-based monitoring of the muddy 568 mangrove coastline of French Guiana. Land Surface Remote Sensing in Urban and Coastal $569 \quad$ Areas 297-320.

570 Walters BB, Rönnbäck P, Kovacs JM, Crona B, Hussain SA, Badola R, Primavera JH, Barbier 571 E, Dahdouh-Guebas F. 2008. Ethnobiology, socio-economics and management of mangrove 572 forests: a review. Aquatic Botany 89: 220-236.

573 Wang L, Sousa WP, Gong P. 2004. Integration of object-based and pixel-based classification for 574 mapping mangroves with IKONOS imagery. International Journal of Remote Sensing 23: $575 \quad 5655-5668$.

576 Wang L, Sousa WP, Gong P, Biging GS. 2004. Comparison of IKONOS and QuickBird images 577 for mapping mangrove species on the Caribbean coast of Panama. Remote Sensing of $578 \quad$ Environment 91: 432-440. 
579 WU (Weather Underground). 2015. Weather History for Labuan, Malaysia. Certified by 580 National Oceanic and Atmospheric Administration (NOAA). Available at 581 http://www.wunderground.com/history.html (accessed 25 May 2015).

582 Xie Y, Sha Z, Yu M. 2008. Remote sensing imagery in vegetation mapping: a review. Journal of $583 \quad$ Plant Ecology 1: 9-23.

584 Zhang X, Treitz PM, Chen D, Quan C, Shi L, Li X. 2017. Mapping mangrove forests using 585 multi-tidal remotely-sensed data and a decision-tree-based procedure. International Journal 586 of Applied Earth Observation and Geoinformation 62: 201-214. 


\section{Table $\mathbf{1}$ (on next page)}

Mangrove cover in Malaysia

State-wise distribution of mangrove cover in West (Peninsular) and East Malaysia (source: Hamdan et al., 2012). 


\begin{tabular}{rrrr}
\hline & State & $\begin{array}{r}\text { Mangrove cover } \\
\text { (ha) }\end{array}$ & $\begin{array}{c}\text { \% } \\
\text { contribution }\end{array}$ \\
\hline 1. Peninsular (West) Malaysia & & & \\
West coast: & Perak & $43,291.97$ & \\
& Johor & $23,676.43$ & \\
& Selangor & $22,530.20$ & \\
& Kedah & $7,841.25$ & \\
& Negari Sembilan & $2,276.50$ & \\
& Pulau Pinang & $1,695.60$ & \\
& Melaka & $1,308.68$ & \\
& Perlis & 94.02 & \\
\hline Total West coast: & - & $\mathbf{1 0 0 , 4 3 8 . 1 5}$ & $\mathbf{1 4 . 1 5}$ \\
\hline East coast: & Pahang & $9,039.26$ & \\
& Terengganu & $2,925.74$ & \\
& Kelantan & 428.95 & \\
\hline Total East coast: & - & $\mathbf{1 2 , 3 9 3 . 9 5}$ & $\mathbf{1 . 7 5}$ \\
\hline & Sabah & $426,334.20$ & \\
\hline T. East Malaysia & Sarawak & $170,533.70$ & \\
\hline & - & $\mathbf{5 9 6 , 8 6 7 . 9 0}$ & $\mathbf{8 4 . 1 0}$ \\
\hline & Total & $\mathbf{7 0 9 , 7 0 0 . 0 0}$ & $\mathbf{1 0 0 . 0 0}$ \\
\hline
\end{tabular}




\section{Table 2 (on next page)}

Accuracy assessment of the supervised classification

Confusion matrix showing the accuracy assessment of species-level mangrove supervised classification at Brunei Bay (Genus names: $\mathrm{R}=$ Rhizophora, $\mathrm{S}=$ Sonneratia, $\mathrm{N}=$ Nypa and $\mathrm{X}$ = Xylocarpus). 


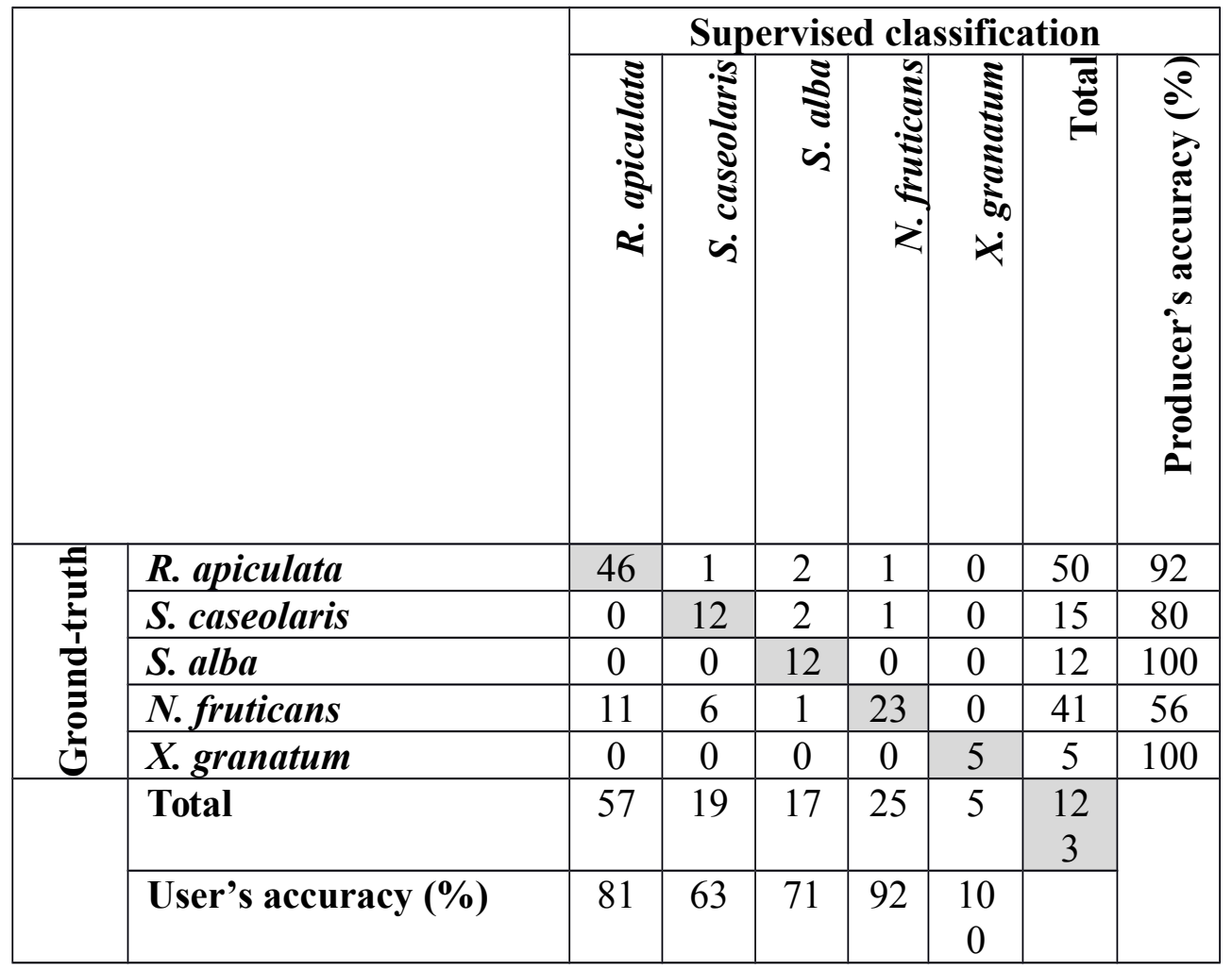




\section{Table 3(on next page)}

Mangrove area

Mangrove area statistics based on supervised classification at the Brunei Bay (Genus names:

$\mathrm{R}=$ Rhizophora, $\mathrm{S}=$ Sonneratia, $\mathrm{N}=$ Nypa and $\mathrm{X}=$ Xylocarpus). 


\begin{tabular}{|c|c|c|c|c|c|}
\hline \multirow[b]{2}{*}{ Species } & \multirow[b]{2}{*}{ Limbang } & \multicolumn{2}{|c|}{ Area (ha) } & \multirow[b]{2}{*}{ Total } & \multirow{2}{*}{$\begin{array}{c}\% \\
\text { contribution }\end{array}$} \\
\hline & & Sundar (up to Sipitang village) & Weston + Menumbok & & \\
\hline R. apiculata & 782.45 & $5,003.25$ & $7,016.19$ & $12,801.89$ & 36.38 \\
\hline S. caseolaris & 751.05 & $1,407.28$ & $3,374.77$ & $5,533.10$ & 15.73 \\
\hline S. alba & 169.37 & 270.11 & 536.90 & 976.38 & 2.77 \\
\hline N. fruticans & $2,566.90$ & $2,728.40$ & $9,583.97$ & $14,879.27$ & 42.29 \\
\hline$X$. granatum & 741.65 & 197.42 & 54.03 & 993.10 & 2.83 \\
\hline Total: & $5,011.42$ & $9,606.46$ & $20,565.86$ & $35,183.74$ & 100.00 \\
\hline
\end{tabular}




\section{Table 4 (on next page)}

Mangrove structural estimates

Mangrove tree structural estimates at Limbang, Sundar, Weston and Menumbok estuaries, Brunei Bay (IV: importance value, Cl: complexity index). 
1

\begin{tabular}{|c|c|c|c|c|c|c|c|c|c|}
\hline Estuary & Species & $\begin{array}{c}\text { Density } \\
\text { (trees 0.1 ha- } \\
\text { 1) } \\
\end{array}$ & $\begin{array}{c}\text { Basal area } \\
\left(\mathrm{m}^{2} \mathbf{0 . 1} \mathrm{ha}^{-}\right. \\
1)\end{array}$ & $\begin{array}{c}\text { Relative } \\
\text { density } \\
(\%)\end{array}$ & $\begin{array}{c}\text { Relative } \\
\text { dominance } \\
(\%)\end{array}$ & $\begin{array}{c}\text { Relative } \\
\text { frequency } \\
(\%)\end{array}$ & IV & $\begin{array}{c}\text { Average } \\
\text { tree height (m) }\end{array}$ & CI \\
\hline \multirow[t]{5}{*}{ Limbang } & $\begin{array}{l}\text { Bruguiera } \\
\text { gymnorrhiza }\end{array}$ & 10 & 0.07 & 5.9 & 0.1 & 10.0 & 16.0 & 6.0 & 844 \\
\hline & Nypa fruticans & 38 & 20.40 & 23.5 & 17.0 & 30.0 & 70.5 & 6.8 & \\
\hline & Sonneratia caseolaris & 77 & 51.41 & 47.1 & 42.8 & 40.0 & 129.9 & 11.7 & \\
\hline & Xylocarpus granatum & 38 & 48.29 & 23.5 & 40.2 & 20.0 & 83.7 & 14.0 & \\
\hline & Total & 163 & 120.17 & 100 & 100 & 100 & & & \\
\hline \multirow[t]{7}{*}{ Sundar } & Avicennia alba & 6 & 0.29 & 4.3 & 0.9 & 6.5 & 11.7 & 11.0 & 303 \\
\hline & N. fruticans & 23 & 14.73 & 17.0 & 44.3 & 16.1 & 77.4 & 6.7 & \\
\hline & Rhizophora apiculata & 54 & 5.25 & 40.4 & 15.8 & 25.8 & 82.0 & 13.0 & \\
\hline & S. alba & 20 & 7.90 & 14.9 & 23.8 & 19.4 & 58.1 & 13.1 & \\
\hline & S. caseolaris & 11 & 0.54 & 8.5 & 1.6 & 12.9 & 23.0 & 9.0 & \\
\hline & $X$. granatum & 20 & 4.53 & 14.9 & 13.6 & 19.4 & 47.9 & 12.3 & \\
\hline & Total & 134 & 33.24 & 100 & 100 & 100 & & & \\
\hline \multirow[t]{6}{*}{ Weston } & B. cylindrica & 8 & 0.20 & 6.1 & 0.6 & 9.7 & 16.4 & 11.4 & 239 \\
\hline & N. fruticans & 31 & 25.91 & 24.2 & 73.8 & 29.0 & 127.0 & 7.7 & \\
\hline & R. apiculata & 20 & 1.55 & 15.2 & 4.4 & 12.9 & 32.5 & 11.6 & \\
\hline & S. caseolaris & 51 & 4.67 & 39.4 & 13.3 & 32.3 & 85.0 & 11.1 & \\
\hline & $X$. granatum & 20 & 2.77 & 15.2 & 7.9 & 16.1 & 39.2 & 11.6 & \\
\hline & Total & 130 & 35.10 & 100 & 100 & 100 & & & \\
\hline \multirow[t]{5}{*}{ Menumbok } & Ceriops sp. & 2 & 0.01 & 1.5 & 0 & 2.9 & 4.4 & 9.0 & 519 \\
\hline & N. fruticans & 42 & 50.01 & 31.8 & 61.6 & 28.6 & 122.0 & 7.9 & \\
\hline & R. apiculata & 74 & 30.56 & 56.1 & 37.6 & 51.4 & 145.1 & 14.9 & \\
\hline & $X$. granatum & 14 & 0.59 & 10.6 & 0.7 & 17.1 & 28.4 & 11.6 & \\
\hline & Total & 132 & 81.17 & 100 & 100 & 100 & & & \\
\hline
\end{tabular}

2 


\section{Figure 1}

Study area location

Location of Brunei Bay in the East Malaysia. The mangrove floristic surveillance was carried out from four major estuarine areas namely, Limbang (box 1), Sundar (box 2), Weston (box 3), and Menumbok (box 4). The town/village names in the vicinity of Brunei Bay were represented by black bullets. Area under the jurisdiction of Brunei Darussalam was masked in yellow colour (ALOS satellite image dated 1 Sept 2010). The white triangle named after MM on the satellite image shows the location of missing mangrove patch on the northernmost corner of Menumbok estuary.
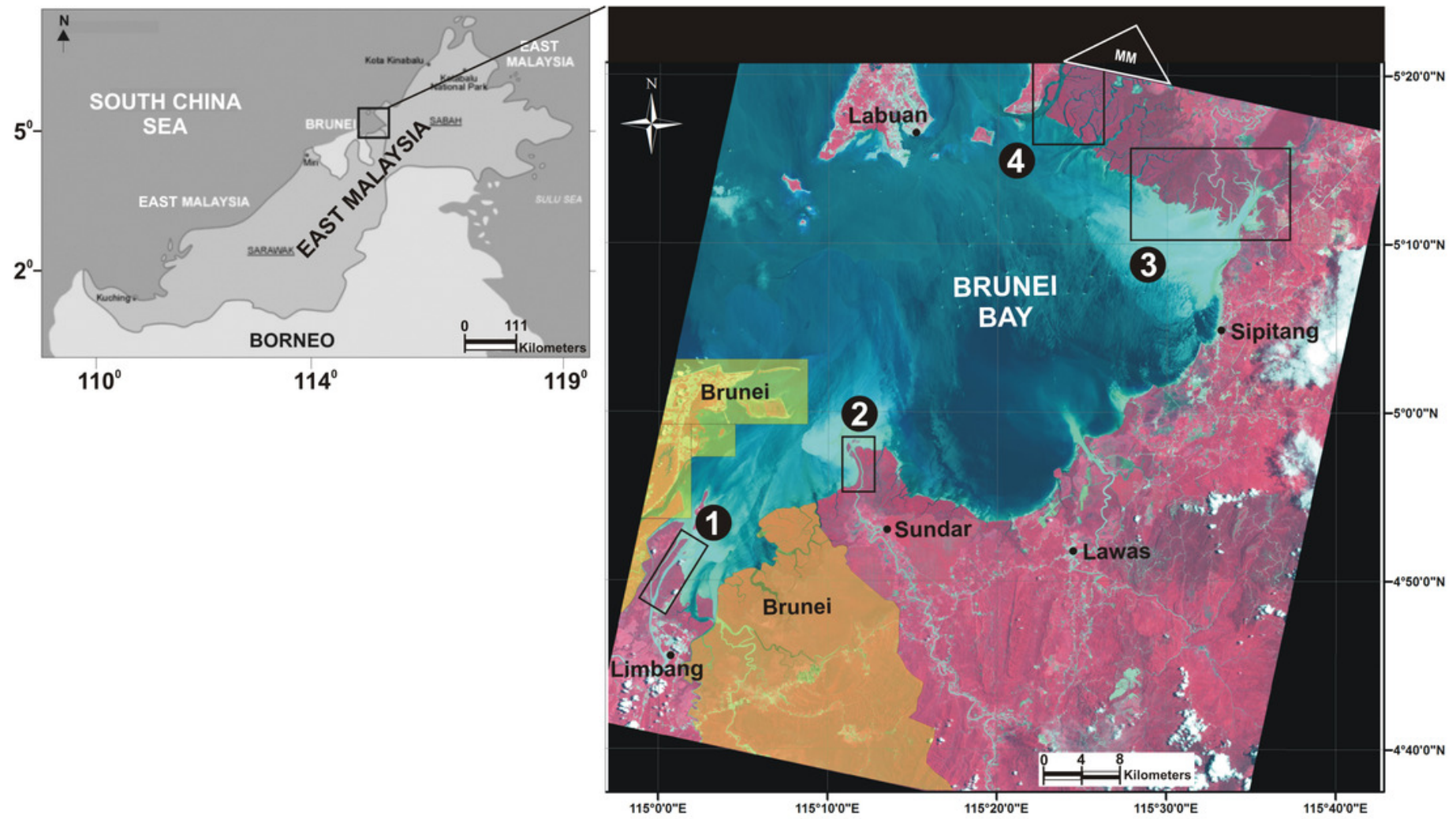


\section{Figure 2}

Mangrove supervised classification

(A) Supervised classification of the mangrove vegetation at Brunei Bay. The species-level distribution of mangroves (white boxes) at - (B) Limbang, (C) Sundar and, (D) Weston + Menumbok estuaries The arrows named after L1, L2 in panel B, S1, S2 in panel C and, W1, W2, M1 and M2 in panel D shows the vegetation survey (PCQM) sampling points at those respective estuarine areas (ALOS single band satellite image dated 1 Sept 2010) (the mangrove area under the jurisdiction of Brunei Darussalam was ignored from image processing/analysis, see Fig. 1 for country's boundary). The white box in panel D shows digitized mangrove cover (from the Google Earth Pro image dated 29 Nov 2014) on the northernmost corner of Menumbok estuary. 

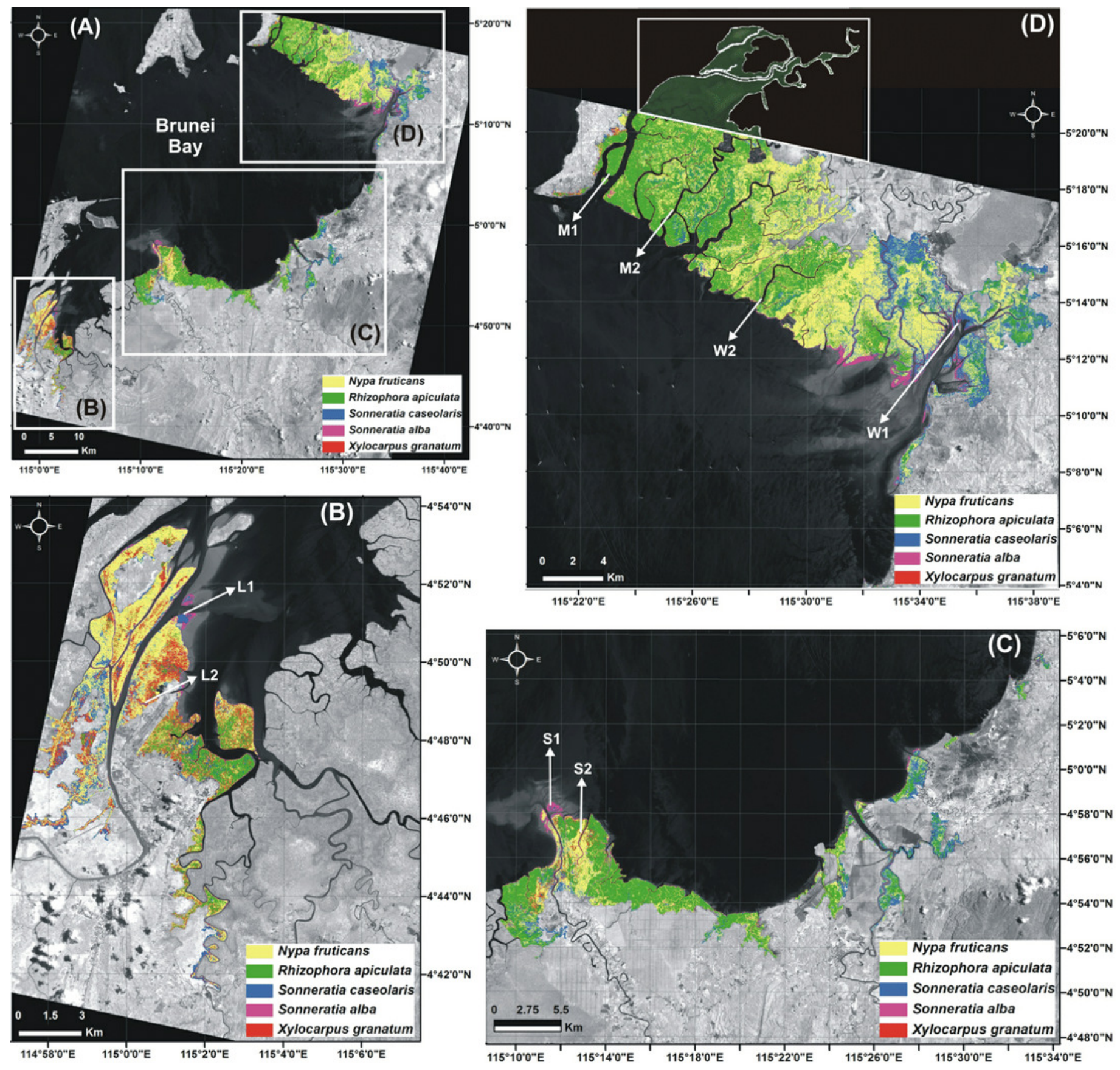


\section{Figure 3}

Pontius matrix

Quantity, Exchange and Shift differences in species-level mangrove supervised classification at Brunei Bay (Genus names: $\mathrm{R}=$ Rhizophora, $\mathrm{S}=$ Sonneratia, $\mathrm{N}=$ Nypa and $\mathrm{X}=$ Xylocarpus). The X-axis refers to the difference (\%) in each mangrove category of the study area.

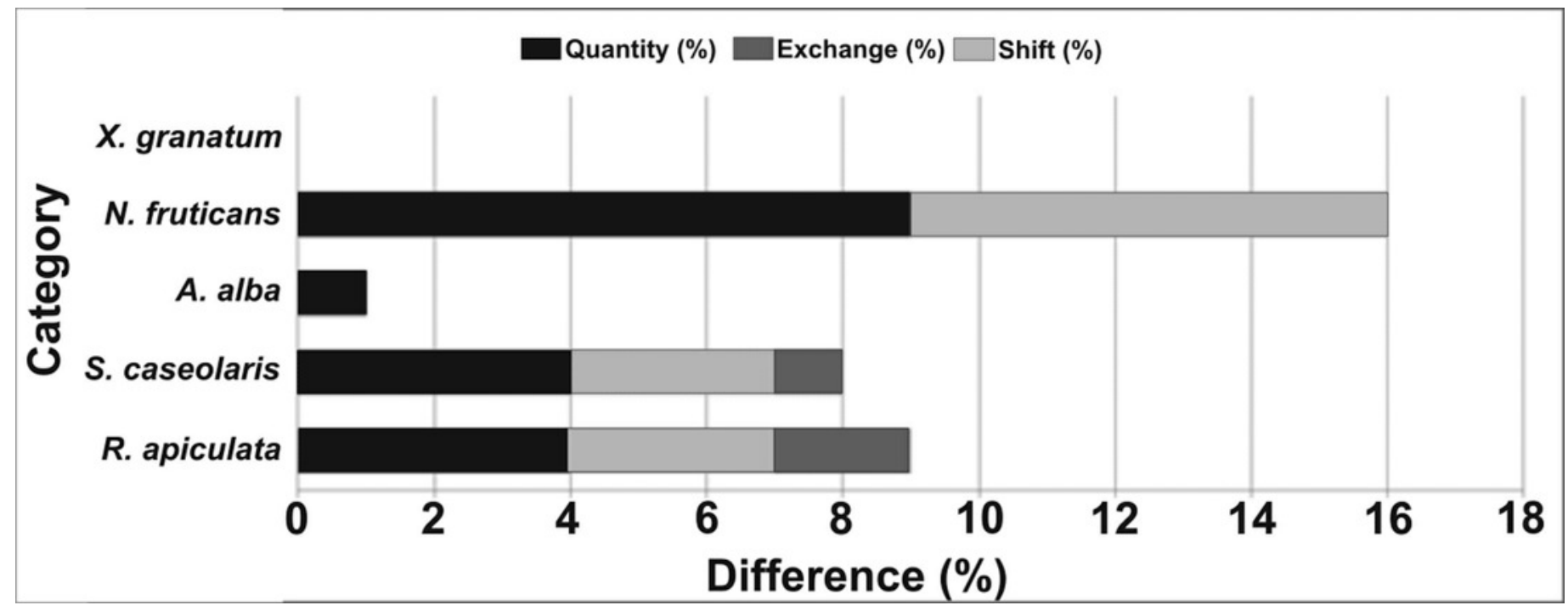


Figure 4

Spectral reflectance of mangrove and non-mangrove vegetation

Average spectral reflectance curves of the dominant mangrove species and the adjacent terrestrial vegetation at Brunei Bay.

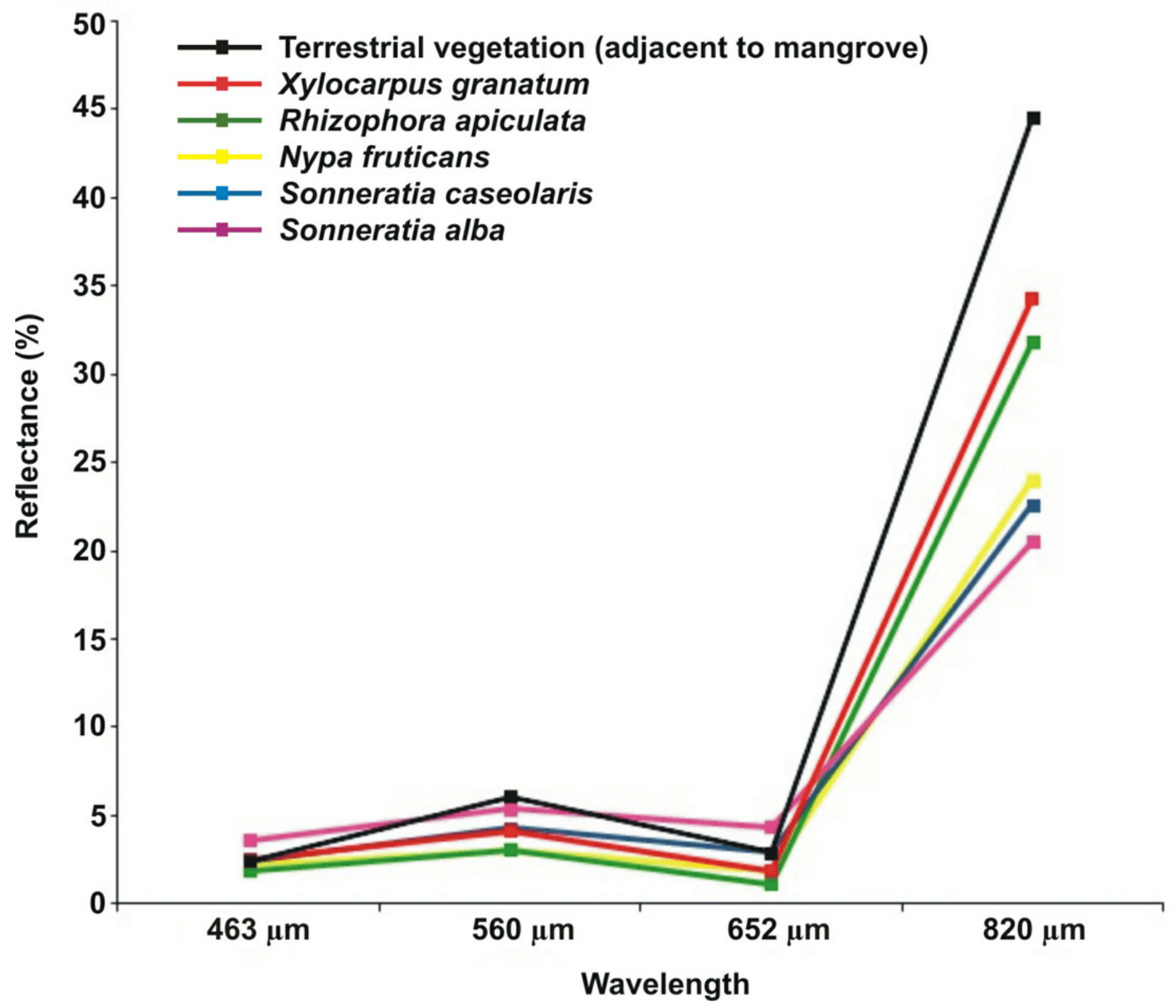


Figure 5

Mangrove diameter distribution

Mangrove diameter class distribution at - (A) Limbang, (B) Sundar, (C) Weston and, (D) Menumbok estuaries. Dotted box in each panel shows the range of diameter contributed by more than $50 \%$ of the trees.
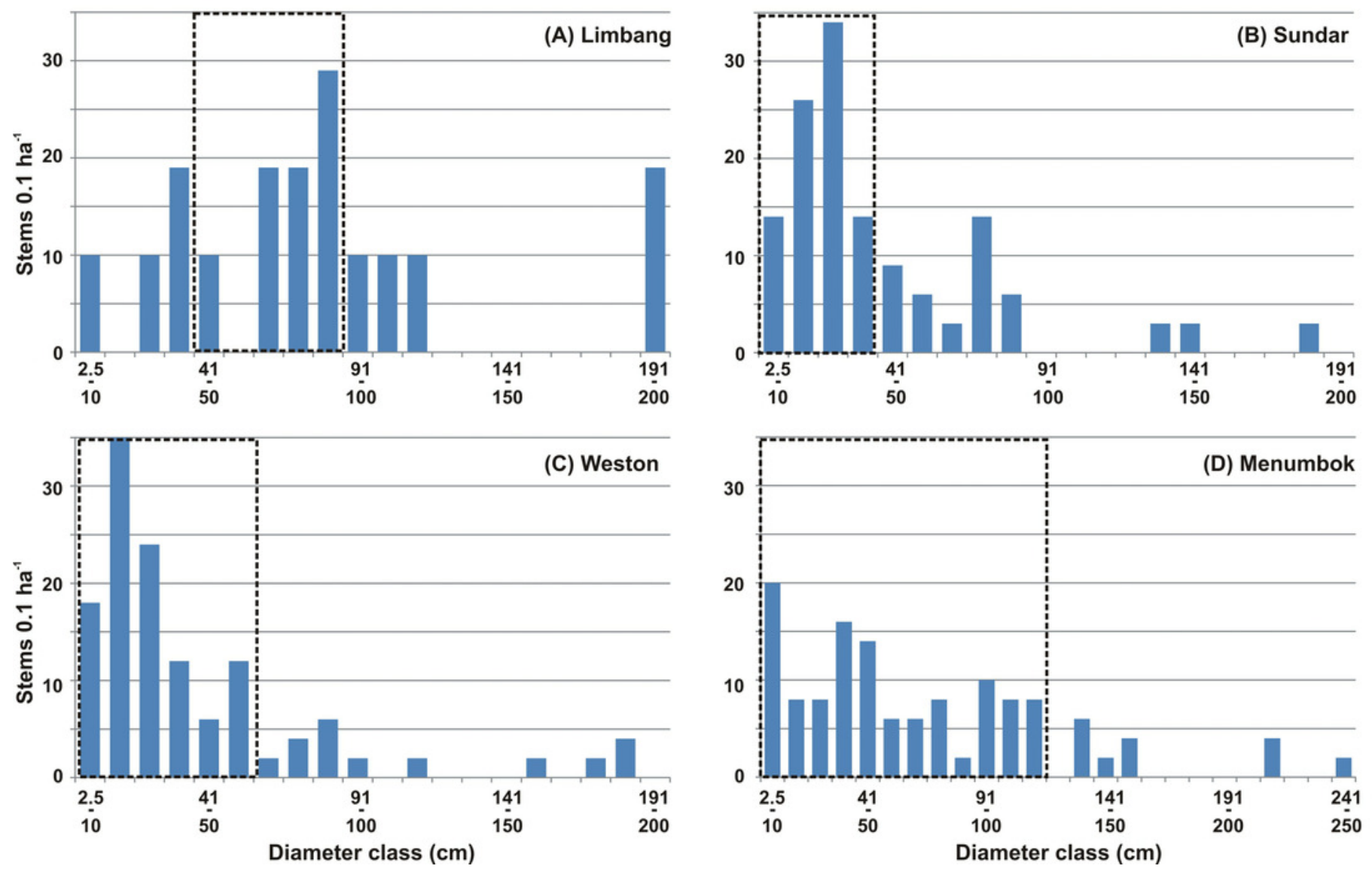


\section{Figure 6}

Fieldwork photographs

Photographic evidences showing - (A) co-dominance of Nypa fruticans and Rhizophora apiculata at Sundar (signboard indicates the existence of crocodiles in this area), (B) codominance of $\mathrm{N}$. fruticans and Sonneratia caseolaris at Weston, (C) succession of S. caseolaris at Limbang river mouth, (D) mangroves facing surplus inundation of the high tide at Sundar, (E) uprooted mangrove trees along the border facing bay waters, (F) dense Rhizophora vegetation at Menumbok (photos taken by Behara Satyanarayana). 

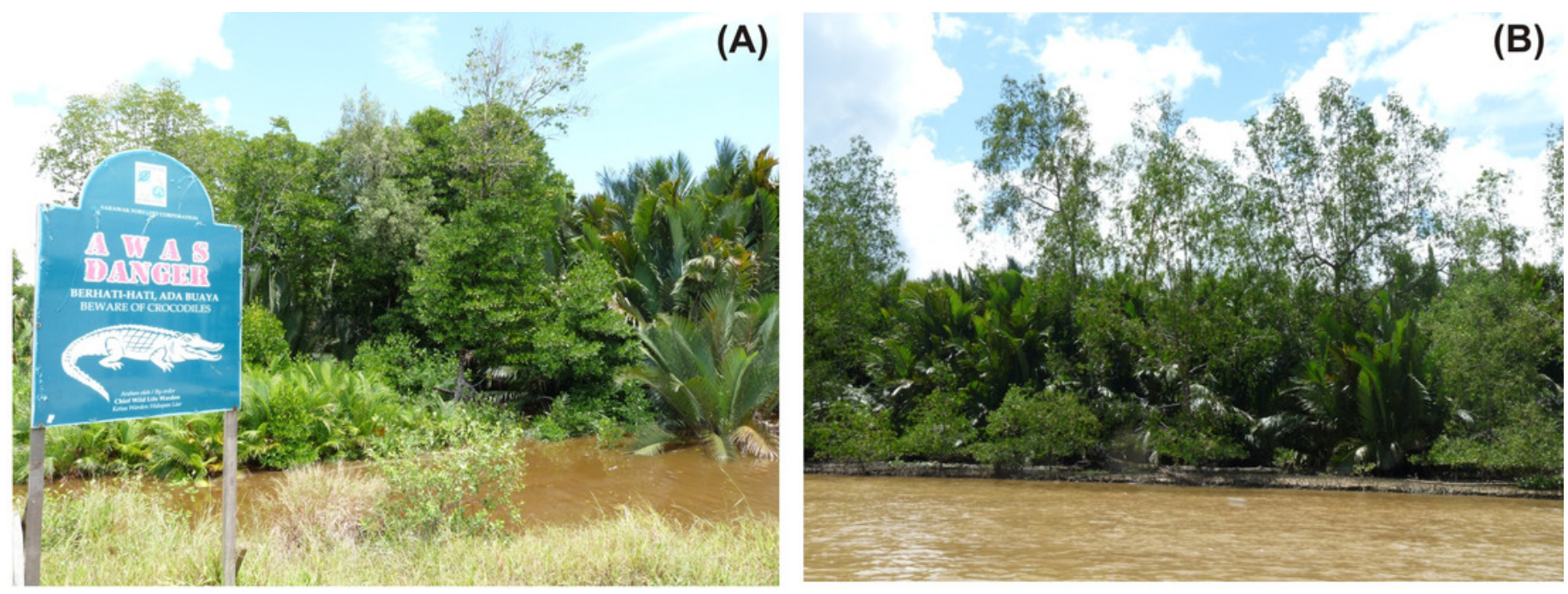

(C)
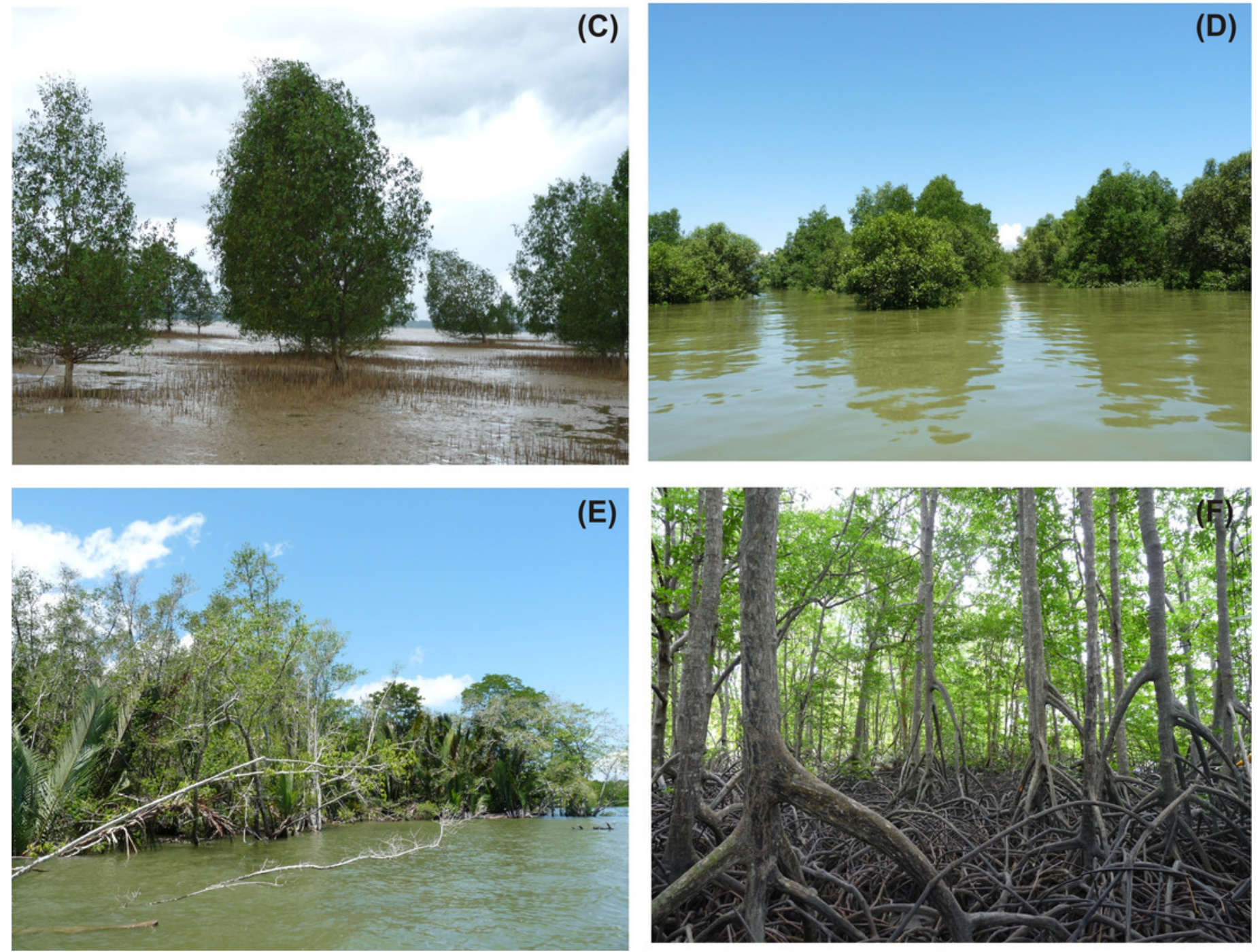